\title{
Subclinical impairment of colour vision among workers exposed to styrene
}

\author{
C Fallas, J Fallas, P Maslard, S Dally
}

\begin{abstract}
The effects of exposure to styrene were studied among 60 men aged 20 to 56 (mean 29.5) employed in shipbuilding. Exposure was due to the handling of glass reinforced polyester materials. The study was cross sectional and the workers were compared with a control group matched for age, social and occupational state, and ethnic origin. During the study, the mean atmospheric exposure to styrene was $24.3 \mathrm{ppm}$. Mean urinary elimination was $230 \mathrm{mg} / \mathrm{g}$ creatinine for mandelic acid and $57.4 \mathrm{mg} / \mathrm{g}$ creatinine for phenylglyoxylic acid. The Farnsworth 100 hue test showed no significant differences between the exposed and control groups for error scores. A significant difference was found, however, for the number of subjects with errors axis in the redgreen, or blue-yellow ranges, or both, which was larger among the exposed workers $(32 / 60 v$ 20/60 for the controls $(p<0.05))$. Psychometric tests were also conducted, using the World Health Organisation (WHO) neurobehavioural core test battery. Of the seven tests it included, anomalies were only found for the aiming test. These results suggest that exposure to moderate styrene concentrations of the order of $25 \mathrm{ppm}$ can lead to impairment of colour vision.
\end{abstract}

Many studies have shown that styrene is a neurotoxic substance. ${ }^{1-4}$ Besides damaging vigilance memorising capacity and other cognitive functions, styrene can also perturb sensory functions, especially of the cochleovestibular region. ${ }^{5}$

On the other hand, there are not many studies of the effects of styrene on visual function, ${ }^{6}$ although

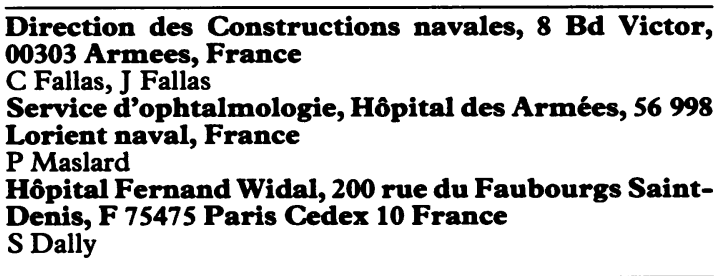

exposure to certain solvents has been shown to lead to dyschromatopsia.? To establish whether or not styrene can cause the same disorder as solvents, we studied colour vision among a group of workers handling polyester resins. This study was combined with a battery of psychometric tests (table 1) developed by the World Health Organisation (WHO) (neurobehavioural test core battery). ${ }^{89}$ The workers were exposed to styrene concentrations currently considered moderately high (about 25 ppm).

\section{Subjects and methods}

The study included 60 men aged from 20 to 56 (mean 29.5) who had been exposed to styrene for periods of one to 29 years (median 3.75 years; mean 6.5 years). All these workers were employed by a shipyard for the construction of ships in glass reinforced polyester materials by contact stratification.

Workers usually wore gloves but not masks. The 60 exposed subjects studied were divided into four groups according to the duration of exposure: group $1, n=14$, exposure < one year; group $2, n=18$, exposure $>$ one year to $<5$ years; group $3, n=14$, exposure $>5$ years to $<10$ years; group $4: n=14$, exposure $>10$ years.

The degree of their exposure to styrene was measured continuously by gas phase chromatography coupled with mass spectrometry, using 16 captors installed in the workshop. During the study period, which lasted three months, the mean styrene concentration measured was $24.3 \mathrm{ppm}$, but there were occasional peaks, the highest of which reached $469 \mathrm{ppm}$. Also, certain tasks were performed in a restricted area, a situation that was not necessarily reflected in the ambient air measurements.

Exposure to styrene definitely predominated, as

\section{Table 1 WHO neurobehavioural core test battery}

\begin{tabular}{ll}
\hline Test & Functional domain tested \\
\hline Profile of mood states (POMS) & Affect \\
Simple reaction time & Attention-response speed \\
Digit span & Auditory memory \\
Santa Ana dexterity test & Manual dexterity \\
Digit symbol & Perceptual-motor speed \\
Benton visual retention & Visual perception-memory \\
Aiming & Motor steadiness \\
\hline
\end{tabular}


the only other substances to which the men were exposed were polyvinyl alcohol and isophtalic resins, both at very low concentrations.

During the study, urinary concentrations of mandelic acid (MA) and phenylglyoxylic acid (PGA) were measured, by high performance liquid chromatography, at the end of the shift on the day of the psychometric tests. The mean values were: MA $230 \mathrm{mg} / \mathrm{g}$ creatinine (2 to 1460 ) and PGA $57.4 \mathrm{mg} / \mathrm{g}$ creatinine $(0.4$ to $421 \cdot 2)$.

The 60 subjects were matched for age, intellectual level, and ethnic origin with 60 male controls who were employed as unskilled workers, boiler makers, or warehousemen, and were not exposed to any particular chemicals.

Both subjects and controls underwent a psychometric examination at the end of their shift, with the method elaborated by WHO-that is, the neurobehavioural test core battery. The procedure included: oral questions concerning social and medical history, occupation, and consumption of medical drugs; a written questionnaire on mood (the profile of mood states (POMS)); a battery of tests comprising simple visual reaction time, digit span, Santa Ana, digit symbol, Benton, and aiming tests. The psychometric examination was conducted in a single session by a trained investigator.

Colour vision was tested during working hours in daylight, with the Farnsworth 100 hue test combined with a specially devised automated procedure for analysis of the results.

No subjects had a history of alcoholism or abnormal biological parameters such as aminotransferase and $\gamma$-glutamyltranspeptidase activity, drug consumption, diabetes mellitus, or hypertension. Two exposed subjects (one for hypertension and one for alcoholism) and three controls (one for education and two for psychiatric history) were not included.
Smoking was similar in the two groups (mean 10 cigarettes a day $v 13.25$ and 37 smokers $v 33$ ).

The results of the psychometric tests for subjects and controls were analysed by comparing the mean raw values obtained. Also, scores were established for each test to compare the distribution of the results among the two populations, in accordance with the method recommended by WHO. The respective numbers of subjects in the exposed and control groups with test results differing by more than one standard deviation from the mean were compared by the $\chi^{2}$ method.

The results of the Farnsworth 100 hue test were analysed by comparing the errors scored in relation to age, according to the parameters established for this method. The red-green and blue-yellow ranges for each subject were noted and the numbers of workers and controls with such ranges compared by the $\chi^{2}$ method.

\section{Results}

No overall significant differences were found for the POMS questionnaire between the results for exposed workers and controls, whether they were analysed according to scores or mean values. There were, however, significant within group differences: in exposure group 2 for fatigue (scores $7.72 v 3.39$, $\mathrm{p}<0.01$ ) and vigour (scores: $15.61 v 18.83$, $\mathrm{p}<0.05$ ) and in group 3 for vigour (scores: $14.29 v$ $17.93, p<0.05)$. No such differences were found for groups 1 or 4 .

For results for the psychometric tests (table 2), the only significant difference between workers and controls was for the aiming test (scores $190 v 206.0$, $\mathrm{p}<0.04$ ).

No significant differences were found between workers and controls for simple visual reaction time.

Table 2 Results of psychometric tests (WHO neurobehavioural core test battery) for workers exposed to styrene and controls

\begin{tabular}{|c|c|c|c|c|c|}
\hline \multirow{3}{*}{$\frac{\text { Score }(\text { mean }(S D))}{\text { Reaction time }}$} & \multicolumn{2}{|c|}{ Exposed workers $(n=60)$} & \multicolumn{2}{|c|}{ Controls $(n=60)$} & \multirow[b]{2}{*}{ p Value } \\
\hline & Mean (SE) & $N o^{\star}$ & Mean (SE) & $N o^{\star}$ & \\
\hline & $23.7 \quad(2 \cdot 9)$ & & $22 \cdot 7 \quad(2 \cdot 4)$ & & NS \\
\hline Reaction time (scatter) & $4 \cdot 5 \quad(2 \cdot 3)$ & & $3.9 \quad(1.7)$ & & NS \\
\hline Digit span & $9 \cdot 6 \quad(1 \cdot 4)$ & 22 & $9.9 \quad(1 \cdot 2)$ & 7 & $\begin{array}{l}<0.01 \\
\text { NS }\end{array}$ \\
\hline Santa Ana (predominant hand) & $45 \cdot 7 \quad(5 \cdot 6)$ & 13 & $45 \cdot 4 \quad(5 \cdot 6)$ & 14 & NS \\
\hline Santa Ana (other hand) & $42 \cdot 5 \quad(5 \cdot 1)$ & 21 & $42 \cdot 7 \quad(4 \cdot 9)$ & 19 & $\begin{array}{l}\text { NS } \\
\text { NS }\end{array}$ \\
\hline Digit symbol & $48 \cdot 9(10 \cdot 2)$ & 23 & $50 \cdot 3 \quad(9 \cdot 1)$ & 18 & $\begin{array}{l}\text { NS } \\
\text { NS }\end{array}$ \\
\hline Benton & $8 \cdot 0 \quad(1 \cdot 3)$ & 16 & $8.0 \quad(1.5)$ & 20 & $\begin{array}{l}\text { NS } \\
\text { NS }\end{array}$ \\
\hline Aiming & $190 \cdot 4(40 \cdot 7)$ & 20 & $206 \cdot 0(41 \cdot 2)$ & 15 & $\begin{array}{l}0.04 \\
\text { NS }\end{array}$ \\
\hline
\end{tabular}

${ }^{\star}$ Number of subjects with results differing by more than one standard deviation from the mean 
Table 3 Results of Farnsworth 100 hue test for workers exposed to styrene and controls, expressed by error scores and the presence of blue-yellow or red-green ranges, or both

\begin{tabular}{|c|c|c|c|}
\hline & Exposed workers $(n=60)$ & Controls $(n=60)$ & p Value \\
\hline $\begin{array}{l}\text { Error score (mean (SD)) } \\
\text { Blue-yellow and/or red-green ranges (No) }\end{array}$ & $\underset{32}{259 \cdot 9}(136 \cdot 9)$ & $\begin{array}{cc}262 \cdot 7 & (114 \cdot 0)\end{array}$ & $\begin{array}{l}\text { NS } \\
<0.05\end{array}$ \\
\hline
\end{tabular}

The scatter was larger, however, for worker values, which exceeded one standard deviation in 22 cases compared with only seven among the controls $(\mathrm{p}<0.01)$. This difference was entirely due to the results for group 4 (eight $v$ one, $\mathrm{p}<0.02$ ) in which there was also a deterioration of digit span (score $9 \cdot 29$ (0.96) $v 10.14(1.06), \mathrm{p}<0.05)$.

The error scores for the Farnsworth 100 hue test showed no significant differences between workers and controls. There was a significant difference, however, for the number of subjects with ranges, which was larger among the workers (table 3 ). The differences were found in the red-green and blueyellow ranges.

\section{Discussion}

The results of this study suggest that exposure to styrene may lead to impairment of colour vision in the form of the anomalies already reported for workers exposed to mixtures of solvents.

These anomalies may reflect toxic damage to the retina, or optic pathways, or both, known to be sensitive to the action of certain solvents such as nhexane ${ }^{10}$ and carbon disulphide. ${ }^{11}$ Here, abnormally frequent ranges were shown, both for discrimination between blue and yellow and between green and red.

On the other hand, the tests for disturbances of mood and cognitive disorders only showed borderline differences between the exposed and control groups; the only significant differences were for the aiming test.

Controversy no longer exists about the neurotoxic nature of styrene, but the acceptable level of exposure is still arguable, especially as regards the maximum value of $50 \mathrm{ppm}$, the accepted limit in many countries. In this connection Mutti et al ${ }^{12}$ found a decline in verbal memory among workers exposed to mean concentrations of the order of $25 \mathrm{ppm}$. Flodin et $\mathrm{al}^{13}$ found that a group of workers exposed to styrene concentrations of the order of $50 \mathrm{mg} / \mathrm{m}^{3}$ complained of fatigue and memory disturbances. The differences between the results of the two studies for the exposed and control groups were confined, however, to one or two subtests. Also, neither Edling and Ekberg ${ }^{14}$ nor Triebig et $a^{15}$ found any differences between exposed and control groups for comparable or higher levels of exposure.

Other studies have shown the existence of anomalies in cochleovestibular function among workers exposed to similar styrene concentrations, ${ }^{16}$ especially a decline in auditory acuity for high frequencies. ${ }^{17}$

In our present study, we only found limited anomalies in the results of the psychometric tests, in agreement with previously published data; however, the abnormally high frequency of dyschromatopsia in the exposed subjects suggests that visual function might be perturbed in exposed workers at an early stage, and that a $50 \mathrm{ppm}$ limit for exposure to styrene might be too high, even though the anomalies found in this study were all infraclinical and therefore not perceived by those concerned.

The Farnsworth 100 hue test is sometimes considered difficult to implement, despite its reliability, due to its great sensitivity. Here, however, the use of a computerised procedure to analyse the results helped to make them easier to interpret. This type of analysis also means that in clinical practices, the Farnsworth 100 hue test takes less time to complete than a psychometric examination. Consequently, for workers exposed to styrene, this colour vision test constitutes a useful means of investigation in addition to the psychometric tests.

We are grateful to the workers and companies who participated in this study, especially to TMT Atlantique in Lorient (France).

1 Gottel $\mathrm{P}$, Axelson $\mathrm{O}$, Lindelof $\mathrm{B}$. Field studies on human styrene exposure. Work Environ Health 1972;9:76-83.

2 Gamberale F, Lisper $H$, Anshelm-Olson B. The effects of styrene vapors on the reaction time of workers in the plastic boat industry. In: Hovath M, ed. Adverse effects of environmental chemicals and psychotropic drugs. Amsterdam: Elsevier 1976;2:135-48.

3 Lillis R, Lorimer W, Diamond S, Selikoff I. Neurotoxicity of styrene in production and polymerisation workers. Environ Res 1978;15:133-8.

4 Cherry N, Waldron $H$, Wells $G$, Wilkinson $R$, Wilson $H$, Jones $S$. An investigation of the acute behavioural effects of styrene in factory workers. $\mathrm{Br} J$ Ind Med 1980;37:234-40.

5 Dolmierski R, Kwiatkowski S, Nitka J. Clinical and experimental research into the pathogenesis of toxic effects of styrene. VII. Appraisal of the nervous system in the workers exposed to styrene. Bull Inst Marit Trop Med Gdynia 1976;27:193-6.

6 Gobba F, Galassi C, Imbriani M, Ghittori S, Candela S. Cavalleri A. Acquired dyschromatopsia among styreneexposed workers. J Occup Med 1991;33:761-5.

7 Mergler D, Belanger S, De Grosbois S, Vachon N. Chromal focus of acquired chromatic discrimination loss and solvent exposure among printshop workers. Toxicology 1988;49: 341-8.

8 Gilioli R, Cassitto MG, Foa V, eds. Neurobehavioural methods in occupatinal health. Oxford: Pergamon Press, 1983.

9 Cassitto MG, Camerion D, Hänninen $H$, Kent Anger W. International collaboration to evaluate the WHO neuro- 
behavioral core test battery. In: Barry L, ed. Advances in neurobehavioral toxicology. Chelsea: Lewis, 1990:203-23.

10 Raita C. N-Hexane maculopathy in industrial workers. Archiv fur Klinisch und Experimentelle Ophtalmologic 1978;209: 99-110.

11 Raïta C, Teir H, Tolonen M, Numinen M, Helpïo E, Malmström $\mathrm{S}$. Impaired color discrimination among viscose rayon workers exposed to carbon disulfide. J Occup Med 1981;23:189-92.

12 Mutti A, Mazzucchi A, Rustichelli P, Frigeri G, Arfini G, Franchini I. Exposure-effect and exposure-response relationship between occupational exposure to styrene and neuropsychological functions. Am J Ind Med 1984;5:275-86.

13 Flodin U, Ekberg K, Andersson L. Neuropsychiatric effects of low exposure to styrene. $\mathrm{Br} J$ Ind Med 1989;46:805-8.

14 Edling C, Ekberg K. No acute behavioural effects of exposure to styrene: a safe level of exposure? Br J Ind Med 1985;42:301-4.

15 Triebig G, Lehrl S, Weltle D, Schaller KM, Valentin H. Clinical and neurobehavioural study of the acute and chronic neurotoxicity of styrene. $\mathrm{Br} J$ Ind Med 1989;46:799-804.

16 Muijser $\mathrm{H}$, Hoogendijk EMG, Hooisma J. The effects of occupational exposure to styrene on high-frequency hearing thresholds. Toxicology 1988;49:331-40.

17 Möller C, Odkvist L, Larsby B, Tham R, Ledin T, Bergholtz DV. Otoneurological finding in workers exposed to styrene. Scand J Work Environ Health 1990;16:189-94.

Accepted 3 February 1992

\section{Vancouver style}

All manuscripts submitted to the $B r J$ Ind Med should conform to the uniform requirements for manuscripts submitted to biomedical journals (known as the Vancouver style).

The $B r J$ Ind Med, together with many other international biomedical journals, has agreed to accept articles prepared in accordance with the Vancouver style. The style (described in full in $\mathrm{Br}$ Med J, 24 February 1979, p 532) is intended to standardise requirements for authors.

References should be numbered consecutively in the order in which they are first mentioned in the text by Arabic numerals above the line on each occasion the reference is cited (Manson' ${ }^{1}$ confirmed other reports ${ }^{2-5} \ldots$. . In future references to papers submitted to the Br J Ind Med should include: the names of all authors if there are six or less or, if there are more, the first three followed by et al; the title of journal articles or book chapters; the titles of journals abbreviated according to the style of Index Medicus; and the first and final page numbers of the article or chapter.

Examples of common forms of references are:

1 International Steering Committee of Medical Editors. Uniform requirements for manuscripts submitted to biomedical journals. Br Med J 1979;1:532-5.

2 Soter NA, Wasserman SI, Austen KF. Cold urticaria: release into the circulation of histamine and eosino-phil chemotactic factor of anaphylaxis during cold challenge. N Engl J Med 1976;294:687-90.

3 Weinstein L, Swartz MN. Pathogenic properties of invading micro-organisms. In: Sodeman WA Jr, Sodeman WA, eds. Pathologic physiology: mechanisms of disease. Philadelphia: W B Saunders, 1974:457-72. 